\title{
Kawasan Rumah Pangan Lestari Sebagai Upaya Peningkatan Ketahanan Pangan Masyarakat Pada Masa Pendemi Covid-19
}

\author{
Nurholis ${ }^{1 *}$ \\ ${ }^{1}$ Prodi Agroteknologi Fakultas Pertanian Universitas Trunojoyo Madura \\ Jl. Raya Telang 02 Kamal Bangkalan Madura 69162 Jawa Timur \\ *E-mail : nurholis@ trunojoyo.ac.id \\ DOI: https://doi.org/10.21107/pangabdhi.v7i1.8635 \\ Naskah diterima 22 September 2020, Revisi 15 Maret 2021, Terbit 29 April 2021
}

\begin{abstract}
Food is anything that comes from biological sources, for example from agricultural, plantation, forestry, fishery and livestock products, both processed and unprocessed which are intended as food or drink for public consumption. The condition of the fulfillment of food for households or the community is reflected in the availability of sufficient food, in quantity, quality, and safe for consumption. In order to achieve food security, food self-sufficiency is needed, namely the ability to provide food from one's own production or independently by utilizing the yard at the household level. Therefore, it is necessary to develop a Sustainable Home Food Area Model (KRPL Model) to optimize the use of yard land which can later meet the food and nutritional needs of the family which in turn will improve the welfare of the community. This activity took place during the implementation of the UTM KKN for the July 2020 period. The activities carried out consisted of introducing the KRPL concept, training, and assistance in managing yards at the household level so that the results of this activity can develop the ability of families and communities economically and socially in meeting needs, food and nutrition in a sustainable manner, leading to a prosperous family and community.
\end{abstract}

Key Words : food for households, nutritional needs, communities, economy

\section{PENDAHULUAN}

Kebutuhan rumah tangga dapat dikelompokkan ke dalam dua kategori besar, yaitu kebutuhan akan pangan dan non pangan. Pada tingkat pendapatan tertentu, rumah tangga akan mengalokasikan pendapatannya untuk memenuhi kedua kebutuhan tersebut. Pangan adalah kebutuhan dasar masyarakat yang harus terpenuhi (Faqih, 2015). Kondisi terpenuhinya pangan bagi rumah tangga atau masyarakat tercermin dari tersedianya pangan yang cukup, baik jumlah, mutu, dan aman untuk dikonsumsi. Guna mewujudkan ketahan pangan diperlukan kemandirian pangan, yaitu kemampuan menyediakan pangan dari produksi sendiri atau secara mandiri dengan memanfaatkan pekarangan ditingkat rumah tangga. Menurut Saptana et al., (2014) terpenuhinya pangan bagi setiap rumah tangga merupakan tujuan sekaligus sebagai sasaran dari ketahanan pangan di Indonesia sehingga pemantapan ketahanan pangan dapat dilakukan melalui pemantapan ketahanan pangan di tingkat rumah tangga. Adawiyah (2011) menambahkan bahwa Penganekaragaman (diversifikasi) pangan dapat menjadi solusi jitu untuk mempertahankan ketahanan pangan nasional. Menurut Kementerian Pertanian (2011), Kawasan Rumah Pangan Lestari (KRPL) merupakan himpunan dari Rumah Pangan Lestari (RPL) yaitu rumah tangga dengan prinsip pemanfaatan pekarangan yang ramah lingkungan dan dirancang untuk pemenuhan kebutuhan pangan dan gizi keluarga serta diversifikasi pangan berbasis sumber daya lokal.

Badan Ketahanan Pangan melalui Pusat Penganekaragaman Konsumsi dan Keamanan Pangan merekomendasikan konsep Kawasan Rumah Pangan Lestari (KRPL), dalam rangka mempercepat penganekaragaman pangan dan memperkuat ketahanan pangan masyarakat. Adanya anjuran pemanfaatan pekarangan sangatlah tepat untuk memenuhi pangan dan gizi keluarga, mengingat selama ini pekarangan dan lahan disekitar lainnya belum dimanfaatkan secara optimal. Padahal lahan tersebut memiliki potensi untuk dikembangkan sebagai penghasil pangan, dalam memperbaiki gizi keluarga sekaligus meningkatkan pendapatan keluarga. Manfaatnya sangat besar, terutama bagi masyarakat golongan ekonomi lemah (Badan Ketahanan Pangan, 2018).

Pemanfaatan lahan pekarangan di areal rumah 
dapet memberikan berbagai manfaat. Pekarangan dapat berfungsi sebagai sumber pangan, plasmanutfah, dan tambahan pendapatan keluarga (Arifin, 2012). Pemanfaatan lahan pekarangan untuk ditanami tanaman kebutuhan keluarga sudah dilakukan masyarakat sejak lama dan terus berlangsung hingga sekarang, namun belum dirancang dengan baik dan sistematis pengembangannya terutama dalam menjaga kelestarian sumberdaya. Oleh sebab itu, komitmen pemerintah untuk melibatkan rumah tangga dalam mewujudkan kemandirian pangan melalui diversifikasi pangan berbasis sumber daya lokal, dan konservasi tanaman pangan untuk masa depan perlu diaktualisasikan dalam menggerakkan kembali budaya menanam di lahan pekarangan (Saliem, 2011).

Dalam rangka penguatan program KRPL pada masyarakat yang melibatkan kegiatan kuliah kerja nyata mahasiswa UTM dengan lembaga penelitian dan pengabdian kepada masyarakat (LPPM) UTM mengadakan pengabdian di daerah pedesaan dan perkotaan khususnya di Kabupaten Bangkalan melalui pemberdayaan rumah tangga. Hal tersebut dilakukan untuk membantu dalam optimalisasi pemanfaatan lahan pekarangan sehingga diharapkan dapat memenuhi kebutuhan pangan dan gizi keluarga yang pada akhirnya akan meningkatkan kesejahteraan masyarakat.

\section{METODE}

Pelaksanaan dilakukan di Desa Banyuajuh Kecamatan Kamal Kabupaten Bangkalan. Lokasi tersebut berada disekitar kampus Universitas Trunojoyo Madura, kurang lebih $4 \mathrm{~km}$ dari kampus. Pelaksanaan dilaksanakan dalam waktu kurang lebih 3 bulan. Pelaksanaan kegiatan dilakukan oleh tim yang terdiri dari dosen Fakultas Pertanian Universitas Trunojoyo dan mahasiswa Kuliah Kerja Nyata (KKN) UTM 2020 yang membantu mulai dari persiapan sampai pelaksaakan kegiatan pengabdian kepada masyarakat ini berakhir.

Metode pelaksanaan dari kegiatan pengabdian kepada masyarakat ini akan dilakukan melalui beberapa tahap, yaitu antara lain survey lokasi, pendataan masyarakat sasaran, pembentukan kelompok sasaran dalam satu dusun atau desa, sosialisasi, pelatihan dan pendampingan kelompok sasaran rumah tangga atau masyarakat dengan mengikutsertakan mahasiswa KKN UTM 2020, dan evaluasi serta monitoring terkait pelaksanaan dan dampak yang ditimbulkan dari kegiatan yang dilakukan.

\section{HASIL DAN PEMBAHASAN}

Kelompok sasaran yang dituju adalah masyarakat rumah tangga di Desa Banyuajuh Kec. Kamal Kab. Bangkalan. Kondisi pemanfaatan pekarangan masih tergolong belum optimal sepanjang pemanfaatannya. Hal ini disebabkan kurangnya kesadaran rumah tangga dan masyarakat dalam penyediaan sumber pangan dan gizi melalui optimalisasi pemanfaatan pekarangan dan lahan disekitar tempat tinggal. Menurut Mardiharini (2011) perhatian masyarakat terhadap pemanfaatan lahan pekarangan masih terbatas sehingga pengembangan berbagai inovasi yang terkait dengan lahan pekarangan belum mencapai sasaran seperti yang diharapkan. Masyarakat kelompok sasaran memiliki luas pekarangan yang beragam yang dapat di kelompokkan menjadi pekarangan pekarangan luas $\left(>400 \mathrm{~m}^{2}\right)$, pekarangan sedang $\left(120 \mathrm{~m}^{2}\right)$, pekarangan sempit $\left(<120 \mathrm{~m}^{2}\right)$, dan sangat sempit (tanpa pekarangan).

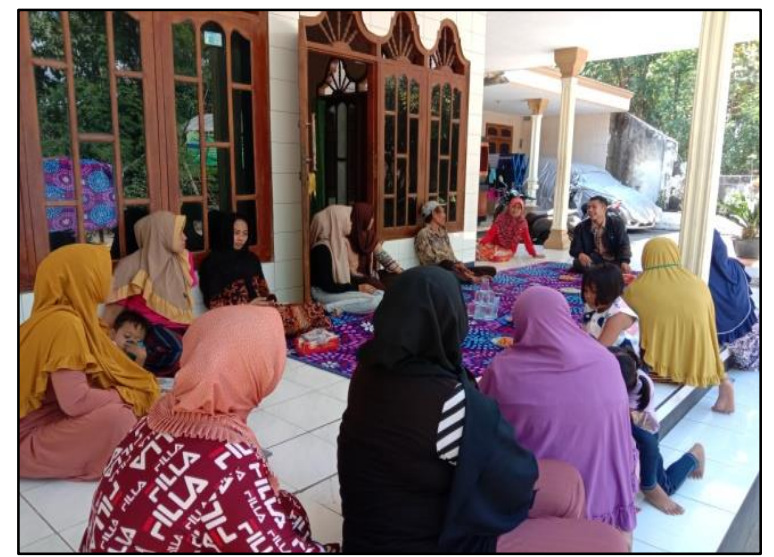

Gambar 1. Sosialisasi KRPL

Konsep kawasan rumah pangan lestari (KRPL) merupakan konsep penumbuhan dan pemanfaatan pekarangan untuk memenuhi kebutuhan pangan dan gizi keluarga secara diversifikasi yang berbasis sumber daya lokal, ramah lingkungan, dan berkelanjutan dalam satu kawasan sehingga diharapkan dapat meningkatkan kemampuan keluarga dan masyarakat secara ekonomi dan sosial (Faqih, 2020). Tujuan dari KRPL ini untuk pemenuhan kebutuhan pangan dan gizi keluarga, mengurangi biaya pengeluaran rumah tangga, penambahan pendapatan keluarga, dan meningkatkan kesejahteraan. Potensi luas lahan pekarangan dan lahan sekitar tempat tinggal rumah tangga atau masyarakat yang belum dimanfaatkan sebagai sumber pangan keluarga. KRPL sebenarnya bukan hal baru dalam masyarakat, karena praktek-praktek menanam dalam skala terbatas (dalam pot) dan banyak jenis tanaman (keragaman tanaman) sudah lama 
dijalankan oleh masyarakat pedesaan maupun perkotaan, namun belum mempertimbangkan aspek pemenuhan pangan dan gizi serta keberlanjutannya.

Konsep ketahanan pangan selalu identik dengan ukuran kemandirian pangan, yakni terpenuhinya kebutuhan pangan (nasional atau kawasan) secara mandiri dengan memberdayakan modal manusia, sosial, dan ekonomi (termasuk lahan pekarangan dan pertanian serta sekitarnya) yang dimiliki, dan berdampak kepada peningkatan kehidupan sosial dan ekonomi masyarakat sehingga mendukung kesejahteraan rumah tangga (Annisahaq et al., 2014). Kemandirian pangan hanya dapat terwujud jika pembangunannya atau penumbuhannya dilaksanakan atas dasar prakarsa (partisipatif aktif) masyarakatnya sendiri sebagai bentuk kesadaran untuk membangun ketahanan pangan yang andal (Purwantini et al., 2012; Nurjannah et al., 2015).

Kegiatan KRPL menggunakan konsep pemberdayaan keluarga dan masyarakat dengan melibatkan seluruh anggota keluarga dan anggota kelompok. Oleh sebab itu, paradigma implementasinya agar dapat berjalan dengan baik dan lancar di lapangan perlu direncanakan dan dilakukan secara partisipatif, disosialisasikan secara informatif dan komunikatif, dan didukung secara terintegratif. Menurut Ashari et al., (2012) perencanaan yang matang dan dukungan lintas sektoral dalam pemanfaatan pekarangan mampu lebih optimal dalam mendukung ketahanan pangan.

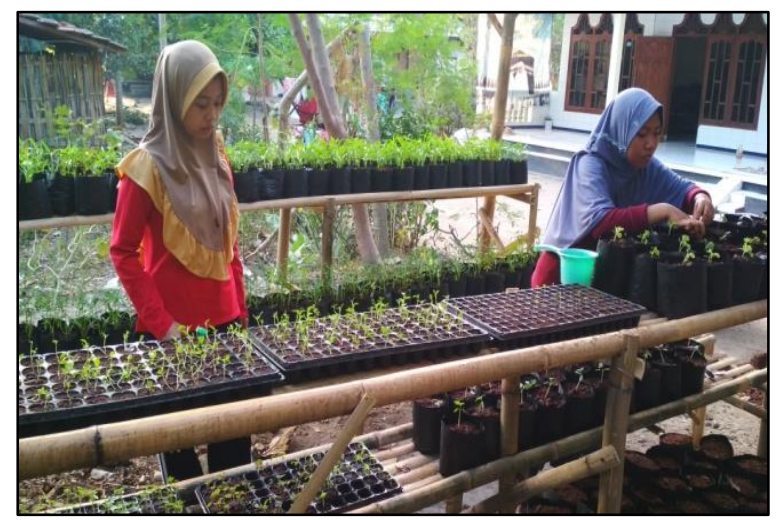

Gambar 2. Kebun Bibit Desa (KBD)

Metode KRPL dilakukan melalui pengembangan pertanian berkelanjutan yang melibatkan partisipasi aktif masyarakat dalam penyedian sarana produksi berupa Kebun Bibit Desa (KBD) sebagai pemasok aneka bibit sayuran dalam penyediaan jenis tanaman hortikultura. Kebun Bibit Desa mempunyai peran yang sangat penting untuk keberlanjutan kegiatan KRPL dalam rangka pengoptimalan pemanfaatan lahan pekarangan

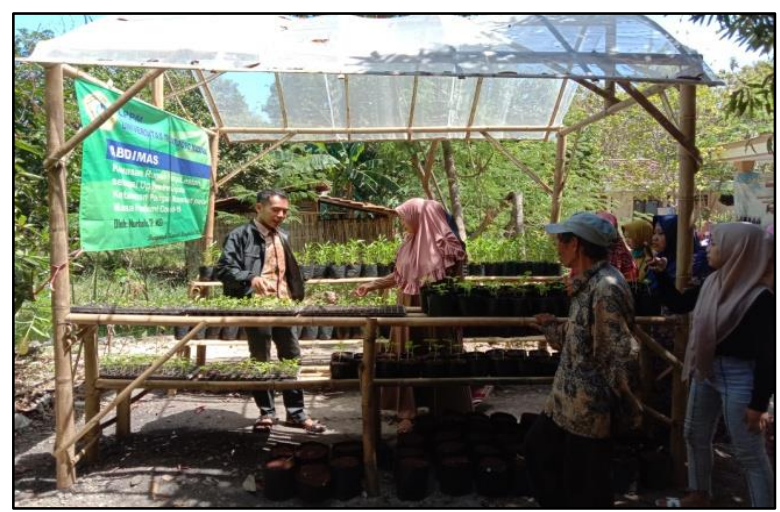

Gambar 3. Partisipasi Aktif Masyarakat

Pengelolaan atau penataan pekarangan yang tepat dapat memberikan manfaat terhadap keindahan lingkungan atau pekarangan sehingga dapat membentuk lingkungan yang asri, indah, nyaman, produktif (Christianingrum, 2020). Hal ini menjadi daya tarik masyarakat lain untuk melakukan replikasi atau implementasi konsep KRPL yang telah dilakukan. Penataan tanaman pada pekarangan disusun secara individu atau bersama-sama seluruh masyarakat yang terlibat dalam kegiatan konsep KRPL dengan memperhatikan estetika dan kepentingan warga. Masyarakat memilih tanaman yang dibudidayakan disesuaikan dengan karakteristik lahan setempat dan kebutuhan masyarakat akan pemenuhan kebutuhan konsumsi atau pangan yang biasa dikonsumsi dan disukai oleh masyarakat sasaran konsep KRPL di Desa Banyuajuh.

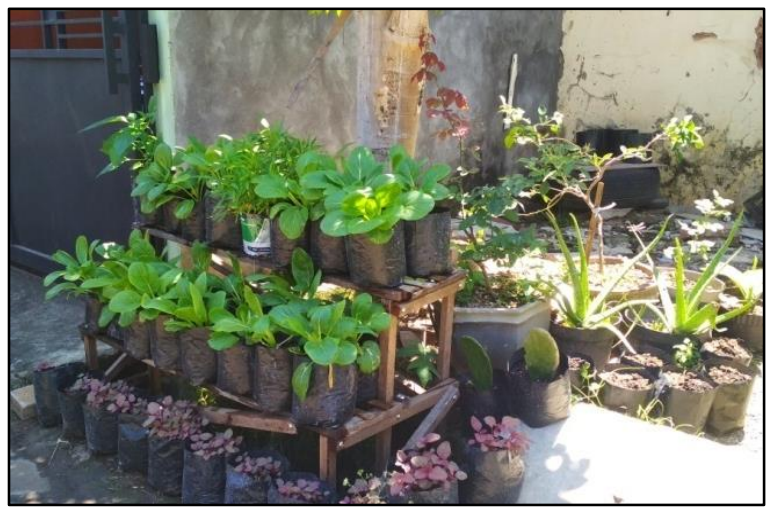

Gambar 4. Implementasi KRPL

\section{KESIMPULAN}

Berdasarkan kegiatan yang telah dilakukan dan hasil yang dicapai dalam pengabdian masyarakat maka dapat disimpulkan bahwa dalam keberhasilan konsep KRPL ditentukan oleh kapasitas SDM masyarakat sebagai pengelola pekarangan, teknologi spesifik lokasi, dan potensi 
sumberdaya lahan pekarangan yang ada. Penerapan konsep Kawasan Rumah Pangan Lestari (KRPL) dapat menambah pengetahun dan ketermpilan dalam pengelolaan dan pemfaatan pekarangan, memberdayakan rumah tangga dan masyarakat dalam penyediaan sumber pangan dan gizi melalui pemanfaatan pekarangan serta meningkatkan kesadaran, peran, dan partisipasi masyarakat dalam mewujudkan pola konsumsi pangan yang beragam yang dapat mengurangi pengeluaran untuk konsumsi pangan keluarga atau masyarakat.

\section{UCAPAN TERIMA KASIH}

Penulis mengucapkan terima kasih kepada LPPM Universitas Trunojoyo Madura yang telah memberikan dana hibah Pengabdian Kepada Masyarakat melalui Hibah Abdimas Tahun 2020.

\section{DAFTAR PUSTAKA}

Adawiyah, C. R. 2011. Memperkokoh Ketahanan Pangan dengan Penganekaragaman pangan. Warta Penelitian dan Pengembangan Pertanian. Vol 33 (6). 5-7 pp.

Annisahaq, H., Nuhfil, H., Syafrial. (2014). Pengaruh Program Kawasan Rumah Lestari (KRPL) dalam Mendukung Kemandirian Pangan dan Kesejahteraan Rumah Tangga. Habitat. Vol 25 (1). 32-39 pp.

Ashari, Saptana, Tri, B. P. (2012). Potensi dan Prospek Pemanfaatan Lahan Pekarangan untuk Mendukung Ketahanan Pangan. Forum Penelitian Agro Ekonomi. Vol 30 (1). 13-30 pp.

Arifin, H. S. (2012). Manajemen Lasnkap Pekarangan bagi Kesehatan Pangan Keluarga. Bogor. IPB Press.

Badan Ketahanan Pangan. (2018). Petunjuk Teknis Optimalisasi Pemanfaatan Lahan Pekarangan Melalui Kawasan Rumah Pangan Lestari

(KRPL).http://bkp.pertanian.go.id/storage/app /media/informasi\%20publik/Pedoman/JUKNI S_KRPL_2018(2).pdf. Diakses pada tanggal
25 Mei 2020.

Cristianingrum, Gigih, I. P. (2020). Penerapan Sistem Kawasan Rumah Pangan Lestari (KRPL) di Desa Baru, Kecamatan Manggar, Kabupaten Belitung Timur. Ikraith-Abdimas. Vol. 3. No. 1. 89-94.

Faqih, A. 2015. Persepsi Anggota Kelompok Tani terhadap Peranan Kelompok Tani; Logika: Jurnal Ilmiah LEMLIT Unswagati Cirebon. Vol 15 (3). 72-89 pp.

Faqih, A. (2020). Pemberdayaan Perempuan Melalui Pemanfaatan dan Penataan Pekarangan. Abdimas Galuh. Vol 2 (1). 1-11 pp.

Kementerian Pertanian. (2011). Pedoman Umum Model Kawasan Rumah Pangan Lestari. Jakarta.

Mardiharini, M. 2011. Model Kawasan Rumah Pangan Lestari dan Pengembangannya ke Seluruh Provinsi di Indonesia. Warta Penelitian dan Pengembangan Pertanian. Vol 33 (6). 3-5 pp.

Nurjannah, R., Yulida, R., Sayamar, E. 2015. Tingkat Partisipasi Anggota Kelompok Wanita Tani dalam Program Model Kawasan Rumah Pangan Lestari (M-KRPL) di Desa Tualang Kecamatan Tualang Kabupaten Siak. Jom Faperta. Vol 2 (1). 1-13 pp.

Purwantini, T. B., Saptan, Sri, S. S. 2012. Program Kawasan Rumah Pangan Lestari (KRPL) di Kabupaten Pacitan: Analisis Dampak dan Antisipasi ke Depan. Analisis Kebijakan Pertanian. Vol 10 (3). 239-256 pp.

Saliem, H. P. (2011). Kawasan Rumah Pangan Lestari (KRPL):Sebagai Solusi Pemantapan Ketahanan Pangan. Kongres Ilmu Pengetahuan Nasional (KIPNAS). Jakarta.

Saptana, Sunarsih, S., Friyatno. (2013). Prospek Model Kawasan Rumah Pangan Lestari (MKRPL) dan Replikasi Pengembangan KRPL. Forum Penelitian Agro Ekonomi. Vol. 31 (1). 67-87 pp. 